
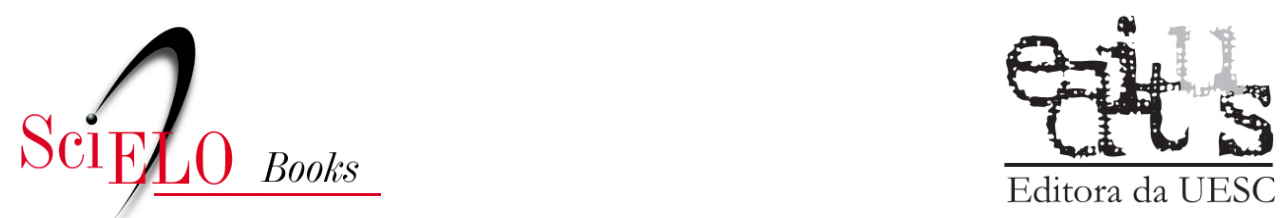

\title{
1 - Bakhtin, o círculo e os gêneros do discurso
}

\author{
Maria Helena Cruz Pistori
}

\section{SciELO Books / SciELO Livros / SciELO Libros}

PISTORI, M. H. Bakhtin, o círculo e os gêneros do discurso. In:

AZEVEDO, I. C. M., ed. Práticas dialógicas de linguagem: possibilidades para o ensino de língua portuguesa [online]. Ilhéus, BA: EDITUS, 2018, pp. 17-42. ISBN: 978-85-7455-494-5.

https://doi.org/10.7476/9788574554945.0001.

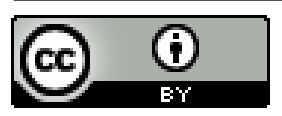

All the contents of this work, except where otherwise noted, is licensed under a Creative Commons Attribution 4.0 International license.

Todo o conteúdo deste trabalho, exceto quando houver ressalva, é publicado sob a licença Creative Commons Atribição 4.0.

Todo el contenido de esta obra, excepto donde se indique lo contrario, está bajo licencia de la licencia Creative Commons Reconocimento 4.0. 


\title{
1
}

\section{BAKHTIN, O CÍRCULO E OS GÊNEROS DO DISCURSO}

\author{
Maria Helena Cruz Pistori ${ }^{1}$ \\ Pontifícia Universidade Católica de São Paulo / CNPq
}

Ser significa ser para o outro e, através dele, para si. O homem não tem um território interior soberano, está todo e sempre na fronteira; olhando para dentro de si, ele olha o outro nos olhos ou com os olhos do outro.

Mikhail Bakhtin ${ }^{2}$

O objeto da linguística é apenas o material, apenas o meio de comunicação discursiva mas não a própria comunicação discursiva, não o enunciado de verdade, nem as relaçốes entre eles (dialógicas), nem as formas da comunicação, nem os gêneros do discurso.

Mikhail Bakhtin ${ }^{3}$

O interesse pelos estudos bakhtinianos no Brasil tem florescido em diferentes áreas: na literatura, na teoria literária, na linguística, linguística aplicada, educação, filosofia, ciências humanas e sociais.

1 Pós-doutorado em Linguística Aplicada e Estudos da Linguagem, sob supervisão da Prof. ${ }^{a}$ Dra Elisabeth Brait, vinculado ao projeto de pesquisa Linguagem e trabalho. Proc. CNPq N. 150095/2014-7; E-mail: <mhcpist@uol.com.br>

2 2006c, p. 341.

32006 b, p. 324. 
Neste artigo ${ }^{4}$, o foco são os estudos de língua e linguagem, para o qual o pensamento bakhtiniano tem inspirado inúmeros estudos, tanto aqueles que nele têm sua única fundamentaçáo teórica e metodológica, - no que tem sido conhecido como Análise Dialógica do Discurso, como os que utilizam algumas de suas noçôes e conceitos complementarmente a outros aportes teóricos. De qualquer forma, devemos reconhecer que não se trata de uma produção intelectual simples - mas fascinante! -, que promoveu e continua a suscitar numerosos debates a seu respeito, dos quais o mais conhecido se refere à assinatura em algumas das obras disputadas.

Com o intuito de introduzir o leitor na obra bakhtiniana, este texto inicia por apresentar, de modo breve, no que e como se constituiu o que hoje conhecemos como Círculo de Bakhtin. A seguir, expóe alguns conceitos elaborados pelo grupo, importantes para a compreensão da língua e das linguagens de modo geral; destaca a importância do conceito de gêneros do discurso na análise e interpretação de qualquer texto, ressaltando, porém, a interdependência e solidariedade entre todas as noçóes bakhtinianas; e, finalmente, mostra como tais noçôes são produtivas na análise de textos e mesmo de um texto verbo-visual, caso do exemplo.

\section{Bakhtin e o Círculo}

Patrick Sériot, no Prefácio da recente edição bilíngue (russofrancês) de Marxismo e filosofia da linguagem (2010), cuja nova tradução, diretamente do russo, é assinada por ele e Inna Tylkowski-Ageeva, lembra que a expressão "Círculo de Bakhtin" surge pela primeira vez apenas em 1967, mencionada pelo psicolinguista

4 Este texto é fruto da videoconferência que proferi no dia 23 de setembro de 2014, a convite da Prof. a Dra Isabel Azevedo, na Universidade Federal do Sergipe; e também da participação na mesa-redonda Argumentação e discurso: definindo objetos de estudos, realizada no II SEDIAR, BH, 2014. 
A. A. Leontiev. Podemos também notar como o termo é pouco familiar ao próprio Bakhtin, que, na entrevista concedida a Duvakin, em 1973, a ele se refere em discurso reportado: "Isso, ultimamente escrevem muito isso"s. Na sequência, relembra alguns dos intelectuais com quem se reunia em Nevel, Vitebski e Leningrado/São Petersburgo, como Pumpianski, Medviédev, Volochínov ${ }^{6}$. Mas o que foi mais exatamente este "Círculo"?

É preciso saber primeiramente que, nas Rússias do período pós-czarista e inicial da Revolução de 1917, a posterior União das Repúblicas Socialistas Soviéticas, vários e produtivos círculos de discussão se constituíam, retomando um hábito comum aos estudiosos russos, o debate coletivo ${ }^{7}$. Trata-se de um período de grande efervescência intelectual e cultural, de muitas transformaçôes sociais, como o combate ao analfabetismo, expansão do ensino superior e de instituiçôes culturais, movimento dos formalistas, e mesmo a crença num Terceiro Renascimento (russo) ${ }^{8}$. No contexto da Rússia e da nascente URSS do início do século XX, um real interesse pela "palavra viva", em estudos muitas vezes realizados por classicistas, levou à criação do Instituto da Palavra Viva (Institut Zhivogo Slova, IZHS). Alguns chegaram a aproximar a democracia grega da ditadura do proletariado, e estudos sobre oratória ocorreram na Rússia durante esta época.

É nesse contexto, no período que vai de 1920 a 1930, que podemos observar a reuniáo, em diferentes espaços políticos, sociais e culturais, de uma comunidade informal de intelectuais de diferentes áreas - filósofos, musicistas, biólogos, linguistas, teóricos da literatura

5 Sériot, 2010, p. 20: "Havia em torno de mim um círculo, que chamam agora de "Círculo de Bakhtin”" (minha tradução); Bakhtin; Duvakin, 2008, p.144.

6 Neste texto, optamos por uniformizar a grafia dos nomes dos membros do Círculo, o que não ocorre nas diferentes ediçôes de suas obras.

7 Outros exemplos são o Círculo Linguístico de Praga ou o Círculo Linguístico de Moscou, formados por intelectuais vinculados à academia (cf. ZANDWAIS, 2009, p. 97-116).

8 Cf. BRANDIST, 2012. 
etc. - que se comunicavam ativamente, discutiam questóes e problemas comuns, liam textos uns dos outros e expressavam as suas opinióes sobre essas leituras. Mais especialmente, construíam uma postura singular em relação à linguagem e a seus estudos. No dizer de Iuri Medviédev e Dária Aleksándrovna Medviédev (2014), em artigo que busca retomar aquelas atividades e nelas destacar o papel de Pavel N. Medviédev, tratava-se de um "coletivo pensante"; assim, a "primeira filosofia” de Bakhtin, a "poética sociológica” de Medviédev e a "sociolinguística” de Volochínov são os elos de uma única cadeia intelectual. Essa reunião constituiu, assim, um pensamento filosófico polifônico único, caracterizado pela cocriação de colaboradores próximos. Lidos com atenção, observamos que os trabalhos reconhecidamente de Mikhail Bakhtin se harmonizam com os demais, de assinatura disputada.

Interessante notar que, no período que vai de 1918 até 1938, os membros do grupo que mais interessam aos estudos da linguagem, Medviédev, Voloshínov e Bakhtin', se encontraram em diferentes cidades (Fig. 1) da extinta URSS ${ }^{10}$. Entre 1918 e 1919, em Nevel, na Rússia Ocidental, a 765 km de Moscou, formou-se o primeiro Círculo, também lembrado como o Seminário Kantiano ou Círculo de Nevel, do qual participavam M. Kagan, L. Pumpianskii, Maria Yudina, Valentin Voloshinov, Mikhail Bakhtin, entre outros. A paixão pela filosofia e pelo debate de ideias - dos antigos gregos até Kant e Hegel - assim como a participação ativa na vida cultural, nos primeiros anos da Revolução, unia o grupo. Mais tarde, entre 1920 e 1924, o grupo se reencontra em Vitebsk, cidade de grande atividade cultural vanguardista, a $500 \mathrm{~km}$ de Moscou e ao sul de Nevel. Àqueles membros de Nevel se junta agora Pavel Medviédev. Nesses dois primeiros períodos, encontramos uma rica produção do

9 Pavel N. Medviédev: *São Petersburgo, 1892 - †Leningrado, 1938; Valentín Nikoláievich Volóshinov: *São Petersburgo, 1894 - †Leningrado, 1936; Mikhail M. Bakhtin: *Orel, 1895 - †Moscou, 1975.

10 Há vários textos que recuperam, espacial e historicamente, a trajetória do Círculo. Sugerimos, entre outros, Brait, B.; Campos, M. I. B., 2009, p.15-30; Clark, K.; Holquist, 2008. 
Círculo, especialmente de Mikhail Bakhtin: Arte e responsabilidade (1919), Para uma filosofia do ato (1920/1924), O problema do conteúdo, do material e da forma na arte verbal (1923/1924), O autor e a personagem na atividade estética: o autor e o herói (1924/1927).

Entre 1924 e 1929, em Leningrado, o Círculo ganha novos membros, como I. Kanaev, e o debate continua, abrangendo questóes como a importância da filosofia da linguagem, suas relaçôes com a psicologia, a filosofia e a poética. É um período de grande produtividade intelectual do grupo, que publica: $A$ palavra na vida e a palavra na poesia (1926), O freudismo (1927), Marxismo e filosofia da linguagem: problemas fundamentais do método sociológico na ciência da linguagem (1929), assinados por Volochínov; $O$ método formal nos estudos literários: introdução crítica a uma poética sociológica (1928), assinado por Medviédev; e Problemas da obra de Dostoiévski (1929), assinado por Bakhtin.

No final de 1928, Bakhtin é preso, sobretudo por seu vínculo com a organização religiosa Ressurreição, não oficial. Hospitalizado em 1929, é exilado em 1930, em Kustanai, no Cazaquistão, a 3000 $\mathrm{km}$ de Moscou. Lá trabalha como economista contábil e redige o importante ensaio O discurso no romance (1934-1935). Logo a seguir, começa a dispersão do Círculo: em 1936, Volochínov morre de tuberculose. No ano seguinte, já em Saransk, capital da Mordóvia, Bakhtin passa a ensinar Literatura no Instituto Pedagógico, sob recomendação de Medviédev, que, no entanto, é fuzilado em 1938. Em Saransk, Bakhtin exerce intensa atividade intelectual, com a produção de mais alguns dos ensaios que se encontram nas coletâneas brasileiras Questöes de literatura e estética: a teoria do romance e Estética da criação verbal; do trabalho sobre Rabelais, A cultura popular na Idade Média e no Renascimento (1940), tese de doutorado defendida no Instituto Gorki, em Moscou, no final de 1946 (só publicada na Rússia em 1965). Na década de 1950, melhora a situação profissional de Bakhtin, que passa a dirigir a cátedra de Literatura russa e estrangeira da Universidade de Saransk, e escreve Os gêneros do discurso, entre outros ensaios. 
Em 1957, ocorre a descoberta de seus trabalhos por V. Kozhinov, G. Gachev e S. Bocharov, este último o coordenador, junto de Kójinov, do projeto de ediçáo das Obras reunidas em sete volumes (M. M. Bakhtin. Sobránie Sotchiniénii v cemi tomax $)^{11}$ : 1 . Textos filosóficos e estéticos do período de 1920; 2. Problemas da obra de Dostoiévski, artigos sobre Tolstoi e notas de leitura sobre a história da literatura russa, período de 1920; 3 . Artigos sobre a teoria do romance, período de 1920; 4. Rabelais e materiais associados (1940-1970); 5. Trabalhos de 1940 até o início de 1960; 6. Problemas da poética de Dostoiévski (reformulaçáo do livro de 1929, é o que conhecemos hoje, no Brasil) e trabalhos de 1960 e 1970; 7. Trabalhos do Círculo, Volochínov e Medviédev. Entre 1969 e 1975, em Moscou, agrava-se o estado de saúde de Bakhtin, que vem a falecer em 1975.

Em relaçáo à questáo da autoria, podemos afirmar que existem basicamente três posiçóes: o respeito à autoria conforme conste das ediçóes originais; a atribuição a Bakhtin de todos os textos disputados; e a inclusão dos dois nomes na autoria, Bakhtin/Volochínov (como na edição brasileira de Marxismo e filosofia da linguagem, por exemplo), Bakhtin/Medviédev. Segundo Faraco (2009, p.11-13), a primeira posiçấo tem sido mais comum atualmente, nas inúmeras traduções existentes ao redor do mundo; além disso, segundo ele, seria uma "forma adequada de respeitar a memória" de todos os autores. É preciso lembrar, ainda, que, em vida, Mikhail Bakhtin teve oportunidade de reivindicar a autoria dos textos disputados, mas não o fez.

A essa questão controversa, juntam-se pontos obscuros de sua própria biografia, sobre a qual pouco se sabe; não se tem certeza nem mesmo de onde ele terminou os estudos universitários, se em Odessa ou São Petersburgo, nem quais foram exatamente esses estudos: filologia clássica, literatura, filosofia... Boris Schnaiderman, profundo conhecedor da obra bakhtiniana, afirma a seu respeito:

11 Sobre as obras completas de Mikhail Bakhtin, publicadas na Rússia, cf. Grillo, 2009. 
"Bakhtin é múltiplo, então ele é contraditório, riquíssimo, variado. Tem que ser assimilado dentro dessa riqueza toda. É nele que existe a polifonia, o dialogismo. Sempre há um Bakhtin dialogando com outro Bakhtin” (2009, p. 224).

Outro desafio que se acrescenta à compreensão da obra bakhtiniana são os problemas de tradução e de sua recepção nos diferentes tempos e espaços. Isso porque cada tradução reflete teoricamente o espaço e o tempo em que ocorreu, isto é, sofre influências do pensamento e da terminologia linguístico-literária corrente naquele momento. Além disso, as traduçóes começam a cruzar as fronteiras soviéticas de forma bastante irregular e acronológica.

É na década de 1970 que Bakhtin começa a ser divulgado no Ocidente. Na tradução para o espanhol de Marxismo e filosofia da linguagem, realizada diretamente do russo em 1976, a obra aparece com o título El signo ideológico y la filosofía del lenguaje, refletindo e refratando o momento ditatorial por que passavam os países da América Latina. Tanto em espanhol quanto em inglês (1973), a autoria é atribuída apenas a Volochínov. A tradução brasileira, de 1979, cheganos a partir da tradução francesa, com Prefácio de Roman Jakobson.

$\mathrm{Na}$ França, a obra do Círculo começa a ser conhecida com Problemas da Poética de Dostoiévski e, em seguida, com a obra sobre Rabelais, inicialmente apresentadas por Julia Kristeva, eminente linguista búlgaro-francesa. Ao dar a conhecer o pensamento de Bakhtin, Julia Kristeva declara que seu objetivo era "situar Bakhtin no contexto francês", "acomodá-lo ao olhar francês, fazer dele um interlocutor da teoria contemporânea dos anos 1960-1970, e não um objeto do passado, colocá-lo diante do leitor francês, cujo espírito é forjado pela linguística e pela psicanálise"12 (SÉRIOT, 2010, p.15).

12 Apenas para exemplificar: a tradução de enunciado/enunciação por "ato de fala" (em Marxismo e filosofia da linguagem), adaptação das ideias filosóficas do Círculo às próprias teorias em que a tradução se inseria (pragmática, de Austin); ou a noção de intertextualidade, presente na tradução para o francês apresentada por Kristeva, que não corresponde exatamente a relaciones dialógicas, que aparece na tradução para o espanhol. 
É justamente em oposição a esse posicionamento que Patrick Sériot, na tradução recente de 2010 para o francês, pretende que seu texto esteja mais próximo da Leningrado de 1929, e mais distante da Paris de 1977, buscando recuperar sua temporalidade e espacialidade próprias (p. 15): "passar do Bakhtin afrancesado para o Volochínov russo é também uma forma de compreender melhor nosso próprio espaço-tempo, nosso próprio cronotopo" (p. 17), diz ele. Atualmente, conhecemos bem mais da obra do Círculo, traduzida em mais 15 línguas, e uma das mais difundidas da URSS no domínio da filosofia da linguagem.

Ao lado das questóes referentes à tradução, existem os problemas referentes às diferentes recepçóes da obra do Círculo, aspecto que também pode dificultar sua compreensão. Em artigo recente na revista Bakbtiniana, Renata C. Marchezan (2013) examina a recepção do pensamento bakhtiniano, destacando o modo particular como alguns autores brasileiros e estrangeiros (J. Kristeva, Ken Hirschkop, Michael Holquist, G. Tihanov, e Craig Brandist, Tzvetan Todorov, Carlos A. Faraco, Geraldo T. Souza, entre outros) dela tratam: ora como uma pragmática, ora uma sociolinguística, uma semiótica, uma teoria social, ou ainda uma teoria do discurso. Aponta ainda o impacto do pensamento bakhtiniano nos campos da pedagogia, da literatura e das meta-humanidades. Ao final, fixa-se, como nós, no domínio da linguagem, considerando, com Brait ${ }^{13}$, que dela se pode depreender uma teoria/análise dialógica do discurso: o discurso como objeto de estudo a partir de um corpo de conceitos pertinentes e de uma metodologia apropriada ao exame dialógico do discurso: "Uma teoria em que, pelo menos no contexto de preocupação com a língua, com a linguagem, se destaca um conceito de diálogo como seu eixo fundador e organizador. Uma teoria dialógica, portanto" (2013, p. 89).

Finalizando este primeiro item: a questáo da autoria, os problemas de tradução - inclusive o fato de as obras terem sido conhecidas

13 Cf. Brait, 2008, p. 9-31. 
no Ocidente fora da ordem em que foram produzidas originalmente, não permitindo que percebêssemos o desenvolvimento do pensamento de seus autores através do tempo; a distância entre o contexto em que foram produzidas - durante o período da Revolução Russa de 1917 e seus posteriores desdobramentos... - e problemas na recepção da obra bakhtiniana requerem que seu estudo seja realizado cuidadosamente e com profundidade, levando todos esses aspectos em consideração.

\section{Dialogia, relaçóes dialógicas e gêneros do discurso}

Antes de apresentarmos alguns dos conceitos básicos que compóem o aparato teórico-metodológico do Círculo adequado à compreensão e interpretação do mundo de discurso que habitamos, é importante destacar algumas importantes observaçóes prévias. Primeiramente, o fato de que os textos do Círculo, mesmo quando tratam de poética ou literatura, podem ser ampliados para a compreensão de qualquer tipo de linguagem ${ }^{14}$. Em segundo, o fato de que nenhum conceito do Círculo pode ser compreendido isoladamente - nem gênero, nem dialogismo, ou relaçôes dialógicas, nem discurso, tema, estilo... Há mais: todos se inter-relacionam, não há como definir um sem que se defina sua ligação com os demais, pois constituem um sistema de pensamento "aberto e dinâmico", em processo, e dependem de uma compreensão responsivo-ativa de ao menos duas consciências.

A linguagem ocupa posição central no pensamento bakhtiniano: ela desempenha importante papel na constituição social da consciência individual, na formação das identidades e na organização de mundos. Na realidade, na comunicação verbal o ser humano

14 Basta lembrarmo-nos do próprio título de um dos mais conhecidos ensaios de Volochínov, A palavra na vida e na poesia, em que o autor, para mostrar o que é o discurso na poesia, parte do discurso cotidiano. 
participa com a totalidade de seu ser, do corpo à palavra. Por isso, antes de tratarmos especialmente da noção de gêneros do discurso na obra de Bakhtin, vamos introduzir alguns conceitos do Círculo, iniciando com a concepção de diálogo.

O diálogo, ou a dialogia, ou o "princípio dialógico", como apropriadamente o chamou Todorov, está fortemente presente no todo da obra bakhtiniana em qualquer das assinaturas e é seu conceito primordial. Para compreendê-lo bem, iniciamos com a reflexão de Volochínov em Marxismo e filosofia da linguagem, ao tratar da interação verbal, que é constitutiva da comunicação humana e realizada por meio das enunciaçóes. É nesse ponto que Volochínov afirma que o diálogo é uma das formas de interação verbal: no sentido estrito, diz ele, designa o diálogo face a face. Mas não é esse o aspecto que interessa ao Círculo. Por isso, a seguir, amplia o conceito, afirmando que é "toda comunicação verbal, de qualquer tipo que seja” (1981, p. 123).

Como? Ele explica, em seguida, iniciando com o exemplo de um livro. Mostra, então, como o livro se constitui parte da comunicação discursiva, na medida em que é objeto de discussóes ativas, comentado, criticado, responde a diferentes concepçóes de mundo, em diferentes esferas da comunicação verbal... Mais ainda, na medida em que responde a enunciados anteriores, cada enunciado-livro faz parte da cadeia de enunciados que constituem a comunicação verbal da humanidade, é um dos elos dessa comunicação. Todas as interaçôes discursivas sempre têm um valor de resposta a algo que já foi dito anteriormente; e/ou serão respondidas no futuro. É da participação nesse elo de interações que lhes advém o sentido, pois o sentido é sempre aquilo que responde a alguma coisa.

Observamos então que, na interação discursiva, o ouvinte/ leitor/interlocutor tem papel essencial no pensamento bakhtiniano, pois a própria compreensão não é vista como passiva, mas ativa e responsiva. Como esclarece Bakhtin:

...o ouvinte, ao perceber e compreender o significado (linguístico) do discurso, ocupa simultaneamente em relação a ele uma ativa posição 
responsiva: concorda ou discorda dele (total ou parcialmente), completa-o, aplica-o, prepara-se para usá-lo, etc.; essa posição responsiva do ouvinte se forma ao longo de todo o processo de audiçáo e compreensão desde o seu início, às vezes literalmente a partir da primeira palavra do falante. Toda compreensão da fala viva, do enunciado vivo é de natureza ativamente responsiva (embora o grau desse ativismo seja bastante diverso); toda compreensão é prenhe de resposta, e nessa ou naquela forma a gera obrigatoriamente: o ouvinte se torna falante (2006a, p. 271).

Essa cadeia ininterrupta de compreensão ativa e dialógica é que constitui as relaçóes dialógicas. E, quanto a elas, o mais importante é nos lembrarmos de que são valorativas, respondem apreciativamente a posicionamentos axiológicos e pontos de vista do outro. Na realidade, a obra bakhtiniana afirma que essas relaçóes podem ocorrer a qualquer parte significante do enunciado, mesmo a uma palavra isolada ou a "outros fenômenos conscientizados desde que estes estejam expressos numa matéria sígnica” (2008, p. 211), como imagens. Assim, por exemplo, se num enunciado, ou mesmo numa palavra, ouvimos a voz do outro, é porque as posiçóes semânticas dialogam.

$\mathrm{Na}$ realidade, essas relaçóes não se expressam na língua, mas no discurso, conceito que passamos a apresentar a partir da obra Problemas da poética de Dostoiévski. Nela Bakhtin esclarece que o foco de sua análise é o

discurso, ou seja, a língua em sua integridade concreta e viva e nấo a língua como objeto específico da linguística, obtido por meio de uma abstração absolutamente legítima e necessária de alguns aspectos da vida concreta do discurso. Mas são justamente esses aspectos, abstraídos pela linguística, os que têm importância primordial para os nossos fins (2008, p. 207). 
A importância de tais aspectos está justamente no fato de que é por meio deles que se expressam as relações dialógicas, que, "embora pertençam ao discurso”, não se realizam verbalmente, são extralinguísticas (2008, p. 208). Mas essa situação extraverbal constitui parte integral e necessária da composição semântica do enunciado concreto, como já afirmava Volochínov no ensaio A palavra na vida e na poesia (VOLOCHÍNOV/BAKHTIN, 2010, p. 157). Enfim, na obra do Círculo, o estudo do discurso é proposto em sua integridade concreta e viva, o discurso situado, espacial e temporalmente, numa determinada esfera da atividade humana, com um autor e um destinatário, cujo sentido é dado na interação do verbal com o extraverbal.

$\mathrm{O}$ estudo do enunciado concreto, unidade da comunicação e não da língua, insere-se na cadeia histórica das enunciaçóes. Uma leitura apressada da obra bakhtiniana, principalmente de Marxismo e filosofia da linguagem, nos capítulos em que Bakhtin/Volochínov tratam das duas orientaçôes do pensamento filosófico linguístico - o "subjetivismo individualista" e o "objetivismo abstrato", pode levar o leitor a imaginar que a obra do Círculo posiciona-se contrariamente à linguística, o que não é verdadeiro. Essa mesma obra, quando os autores propóem a ordem metodológica para o estudo da língua (1981, p. 124), ressalta o valor dos estudos da língua/ linguagem, pois coloca a necessidade de também se examinarem as "formas da língua na sua interpretação linguística habitual". E devemos destacar que a crítica de Mikhail Bakhtin e do Círculo referem-se aos limites da linguística, que a "metalinguística" permite suplantar, na medida em que seu foco é o discurso, que conjuga o verbal e o extraverbal. Por isso, ambas "devem completar-se mutuamente e não fundir-se” (2008, p. 207), diz Bakhtin.

Desse modo, é dentro desse espectro amplo da autêntica vida do discurso, integridade viva e concreta da linguagem ou comunicação dialógica, que a noção de gênero discursivo se destaca com ênfase, aparecendo nos textos do Círculo de Bakhtin desde seu início (Cf. BRAIT; PISTORI, 2012). Ou seja, é noção que permanece importante ao longo dos cinquenta anos de produçáo intelectual do grupo, 
embora seja mais conhecida entre nós pelo ensaio de Mikhail Bakhtin, Os gêneros do discurso, escrito entre 1951e 1953, e publicado na Rússia pela primeira vez numa coletânea em 1979, leitura imprescindível para qualquer analista do discurso. Como sabemos, naquele ensaio diz ele que "cada enunciado particular é individual, mas cada esfera de utilização da língua elabora seus tipos relativamente estáveis de enunciados, os quais denominamos gêneros do discurso" (2006a, p. 261-262). Bakhtin destaca aí os três elementos indissoluvelmente ligados no todo do enunciado: o conteúdo temático, o estilo e a composição, que se expressam de modo particular nas diferentes "esferas da atividade humana”, social, cultural e historicamente consideradas (Ibid., p.265).

Nos trabalhos da década de 1920, tanto nos assinados por Volochínov, quanto por Medviédev, já encontrávamos várias vezes a menção aos gêneros linguísticos e, inclusive, a promessa de que deveriam ser estudados "em conexão com o problema da enunciação e do diálogo", já que "cada época e cada grupo social têm seu repertório de formas de discurso na comunicação sócio-ideológica. A cada grupo de formas pertencentes ao mesmo gênero, isto é, a cada forma de discurso social, corresponde um grupo de temas" (BAKHTIN/VOLOCHÍNOV, 1981, p. 43).

Em Problemas da poética de Dostoiévski, no capítulo que trata das Peculiaridades do gênero, do enredo e da composição das obras de Dostoiévski, a ênfase é dada ao dinamismo da própria noção, pois Bakhtin diz que o "gênero sempre é e não é o mesmo, sempre é velho e novo ao mesmo tempo [...] O gênero vive do presente, mas sempre recorda o seu passado, o seu começo" (2008, p. 121). Importante notar que o filósofo russo estava tratando de literatura, mas a noção se estende a qualquer enunciado. E tais observações nos fazem pensar em tantos novos gêneros que surgem com a tecnologia, por exemplo, uma videoconferência... Ou o blog, o email, o Facebook - não surgiram do nada... O email, por exemplo, é um claro sucessor da carta.

Na obra de Medviédev, de 1928, O método formal nos estudos literários. Introdução critica a uma poética sociológica, o foco 
também é a literatura e, basicamente, a refutação dos estudos literários realizados pelos formalistas russos. Mas, no capítulo Os elementos da construçáo artística, a crítica ao modo como eles procuram depreender o gênero da obra tão somente em seus aspectos formais (estrutura composicional, recursos lexicais, por exemplo) faz com que o autor levante questôes fundamentais para a compreensão do que sejam os gêneros do discurso de acordo com o Círculo. Assim, em sua proposição de uma poética sociológica, Medviédev insiste na necessidade de se considerar a totalidade concluída e solucionada da obra - isto é, não apenas os aspectos formais, mas a totalidade realizada por sujeitos socialmente organizados em diferentes esferas de atividade, para dela se depreender o gênero. Mostra a relação entre a obra literária e a realidade, e, muito importante! - chama a atenção para o fato de que cada gênero é capaz de controlar apenas alguns aspectos definidos da realidade, pois cada gênero concebe uma visão de mundo que lhe é própria.

Só para exemplificar: o discurso cotidiano utiliza indiferentemente furto ou roubo; o discurso jurídico compreende e define cada uma dessas açóes a partir de código específico, o código penal. Outro exemplo: o próprio termo gênero, na esfera gramatical, tem um sentido; na análise do discurso, outro; e no uso cotidiano, outro ainda. A mesma coisa acontece, por exemplo, com a noção de discurso que, na linguagem cotidiana tem um significado, mas, se tratamos da Análise do Discurso, outro (ou outros). Ou da expressão obra de arte que, na engenharia, refere-se a uma ponte ou viaduto. Como podemos ver, cada gênero do discurso realmente ilumina a realidade de uma maneira determinada.

Outro importante aspecto da noção, que fica bastante claro na exposição de Medviédev, é que os gêneros se caracterizam por uma dupla orientação dialógica, em íntima e tensa correlação: a primeira orientação é externa: relacionada à vida - tempo, espaço e esfera ideológica definidos; a segunda orientação é interna: relacionada às formas, estruturas e conteúdo temático do enunciado. 
Assim, o enunciado concreto de qualquer gênero é constituído pela língua sendo usada em determinadas condiçóes e assumindo posicionamentos que dáo ao enunciador a condiçấo de sujeito.

O gênero dá forma à obra; seus elementos estruturais, assim como a seleçáo dos recursos lexicais e gramaticais, expressam a relaçáo valorativa do locutor com o objeto do discurso, e só podem ser compreendidos em conjunto e na relaçáa com o gênero. Há, pois, uma clara articulação entre visão de mundo, valoração e gênero, exatamente na medida em que o conteúdo temático de uma obra é inseparável das circunstâncias de lugar e de tempo, é orientado pela realidade circundante e emitido por um sujeito. $\mathrm{O}$ gênero define ainda as relaçôes locutor/interlocutor, de hierarquia, igualdade, inferioridade... Mas lembremos: "é impossível alguém definir sua posição sem correlacioná-la com outras posiçóes. Por isso, cada enunciado é pleno de variadas atitudes responsivas a outros enunciados de dada esfera da comunicação discursiva” (2006a, p. 297).

Finalmente, antes de partirmos para a prática, por meio da análise de uma publicidade a partir dos conceitos bakhtinianos, devemos retomar a metodologia que eles sugerem para a realizaçáo de tal tarefa. Esta, então, a ordem metodológica para o estudo da língua que seguiremos:

1. As formas e os tipos de interação verbal em ligação com as condiçôes concretas em que se realiza.

2. As formas das distintas enunciaçóes, dos atos de fala se isolados, em ligação estreita com a interação de que constituem os elementos, isto é, as categorias de atos de fala na vida e na criação ideológica que se prestam a uma determinação pela interação verbal.

3. A partir daí, exame das formas da língua na sua interpretação linguística habitual (BAKHTIN/ VOLOCHÍNOV, 1981, p.124). 


\section{As relaçóes dialógicas polêmicas: a campanha publicitária de Oliviero Toscani para a Benetton}

Vejamos aqui como o pensamento bakhtiniano, tanto teórica quanto metodologicamente, pode nos auxiliar a compreender discursivamente um texto do gênero publicidade, cujo plano de expressão conjuga o verbal e o visual - um outdoor da Benetton, parte da campanha publicitária realizada por Oliviero Toscani para a empresa italiana. Vamos observar o modo como o sentido se constrói justamente na relação entre o verbal, o visual e o extraverbal.

Em relação às condições concretas de produção, primeiramente é importante lembrar que são bastante conhecidas as campanhas publicitárias da marca Benetton. Sempre provocativas, com belíssimas e coloridas fotografias de Oliviero Toscani, famoso publicitário italiano, elas aparecem em outdoors e vitrines da grife pelo mundo afora. Ora causam estranheza, ora dúvida, ora críticas - temas tão graves (ou tabus...) e causas humanitárias importantes poderiam/ deveriam ser utilizados na publicidade? ; ora não estamos bem certos de tê-las compreendido corretamente. Muitas vezes, causam polêmicas judiciais ${ }^{15}$. Além disso, por parecerem fugir às coerçôes do gênero e não apresentarem o produto a ser comercializado - apenas sua marca, é comum a pergunta: são persuasivas? Será que realmente vendem os produtos da grife? Instigantes como são, já provocaram numerosos artigos e estudos, principalmente na área publicitária.

O grupo Benetton é uma empresa transnacional italiana de moda, com sede em Treviso, fundada em 1965. De modo geral, as publicidades da marca buscam criar uma imagem de grupo responsável, receptivo às necessidades e problemas atuais e atento ao meio

15 Mas, sobre elas, chama-nos a atenção a declaração de seu autor de que não há imagens chocantes, apenas realidade chocante: "There are no shocking pictures, only shocking reality”, in: <http://edition.cnn.com/2010/WORLD/europe/08/13/oliviero.toscani/index.html> 
ambiente, à dignidade humana e à transformação da sociedade ${ }^{16}$. Alguns dos temas apresentados nas publicidades da empresa, desde o final da década de 1980, foram a pena de morte, a guerra na Bósnia, a Aids, a fome, o trabalho infantil, os assassinatos pela Máfia, todos temas sociais polêmicos e bem atuais. No site da empresa, ela se define como "uma empresa que cria valor e almeja o crescimento não como um fim em si mesmo, mas como um meio para contribuir cp o progresso".

A seleção que apresentamos (Fig. 1) dá conta de alguns outdoors de combate ao preconceito racial e religioso. E todos fazem parte da campanha UNHATE, patrocinada pela marca, embora nem todos apresentem o termo. Lançada em 2011, segundo o site ${ }^{17}$, a campanha UNHATE é parte de uma estratégia de incorporar responsabilidade social à empresa e, declaradamente, lutar contra a cultura do ódio. Isto é feito com imagens controversas, que provoquem reaçóes variadas no receptor, apelando a sentimentos de tolerância e humanidade. Nas publicidades selecionadas, encontramos, da esquerda para a direita, primeiramente um padre e uma freira se beijando; a seguir, o presidente americano Barack Obama beijando o presidente da China, Hu Jintao; o papa Bento XVI beijando um imame egípcio; e abaixo, uma série de fotos de jovens de nacionalidades e etnias diferentes em torno do Art. I da Declaração Universal dos Direitos Humanos, escrito em inglês: "Todos os seres humanos nascem livres e iguais em dignidade e direitos". Em todos esses cartazes, o logo da marca se localiza à direita - letras brancas num retângulo verde.

16 Disponível em: <http://www.benettongroup.com/>

17 Disponível em: <http://unhate.benetton.com/> 
FIGURA 1 - Variadas campanhas produzidas por Oliviero Toscani

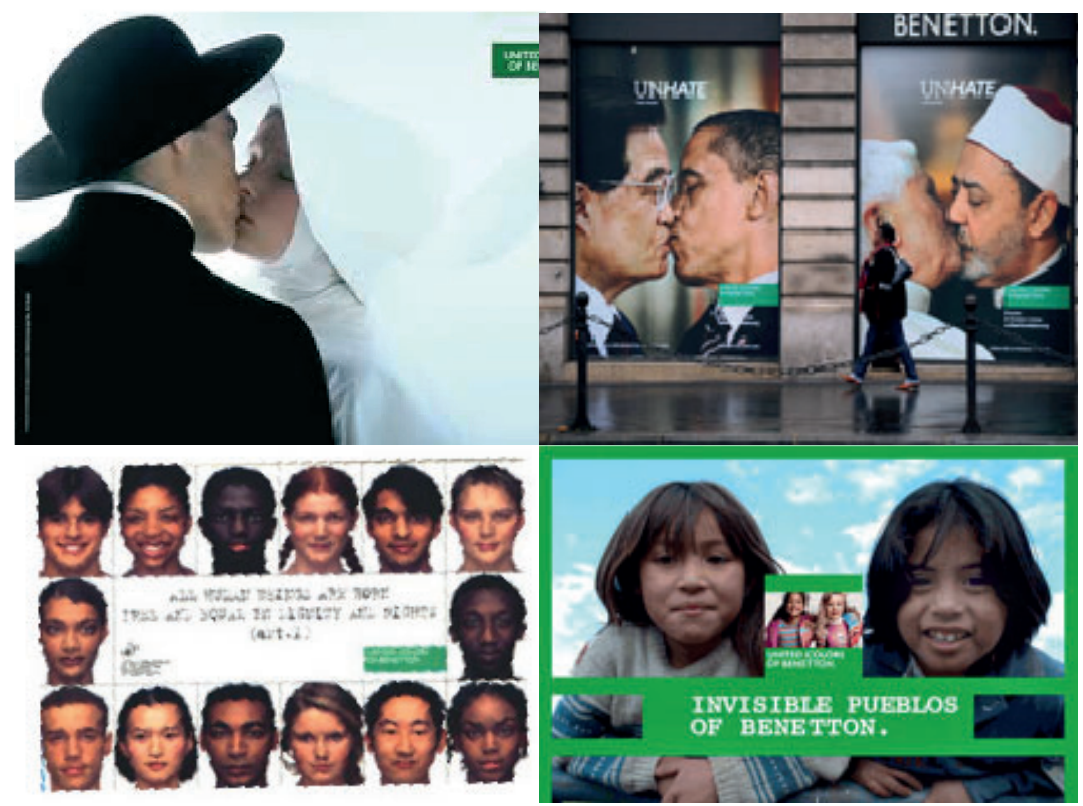

Fonte: Google imagens (Acesso em: 20. out. 2014)

A última imagem, no canto inferior à direita, é um pouco diferente: o logo verde com as letras brancas - United Colors of Benetton, encontra-se centralizado, sob a foto de duas crianças, uma loira e outra morena, também centralizada. Elas, porém, não são o tema predominante neste cartaz. Em tamanho grande, de cada lado da foto pequena, a foto de outras duas crianças de etnia indígena; pela roupa desgastada que vestem, percebe-se que são visivelmente mais pobres que as do centro. $\mathrm{O}$ verde do logo emoldura a foto, e o letreiro Invisible Pueblos of Benetton abaixo das crianças indígenas intriga. $\mathrm{Na}$ realidade, temos aí a paródia da publicidade original da empresa, mas com orientação diversa: está voltada para criticar justamente a campanha humanitária de combate ao preconceito. Trata-se de uma alusáo à compra de quase um milháo de hectares de terra realizada pela Benetton no sul da Argentina e Bolívia. A população local, a maioria pertencente à etnia indígena Mapuche 
- retratada na foto, foi forçada a deixar a área. Por isso, invisíveis... $\mathrm{O}$ processo judicial correu ao longo de vários anos.

Selecionamos adiante (Fig. 2), um outdoor da campanha - este também de Oliviero Toscani, para descrever, analisar e interpretar, de uma forma mais detalhada. Lembremos inicialmente que devemos observar o texto em ligação estreita com o gênero a que pertence. Para isso, é fundamental conhecermos basicamente as coerçóes do gênero publicidade. E, neste caso, também do gênero propaganda, pois ambos parecem e estão muito próximos. De uma forma bastante simplificada, que naturalmente poderia ser aprofundada, observamos que ambos - publicidade e propaganda - apresentam um caráter informativo e uma força persuasiva. A publicidade, porém, caracteriza-se por seu aspecto comercial, enquanto a propaganda, pelo aspecto de divulgação de ideias ${ }^{18}$.

FIGURA 2 - Campanha publicitária polêmica

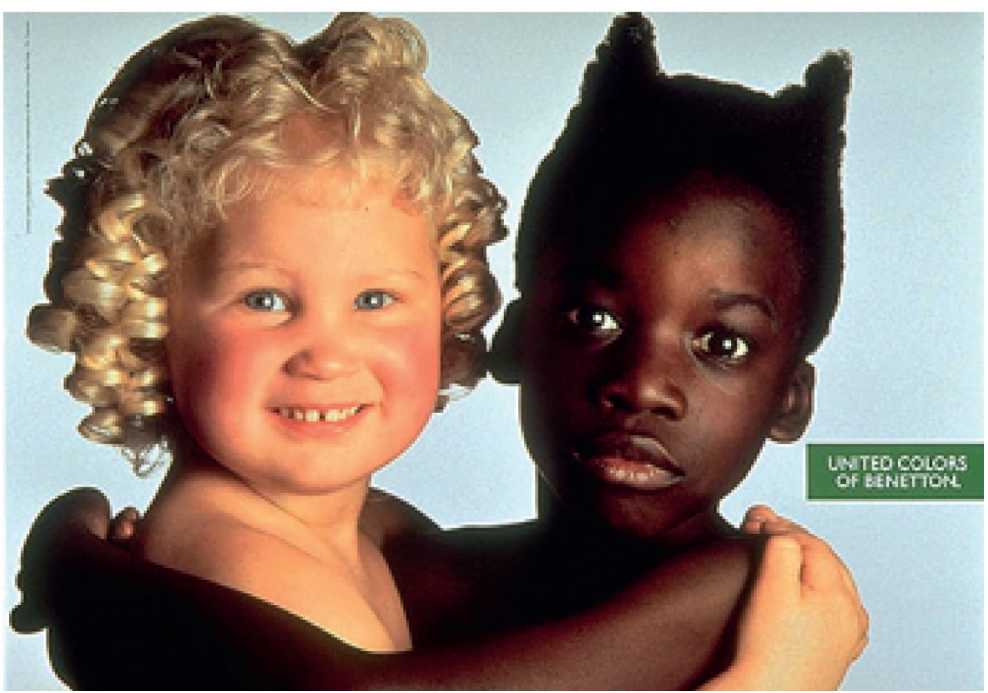

Fonte: Google imagens (Acesso em: 20. out. 2014).

18 Sobre os gêneros publicidade e propaganda, cf. Pistori, 2014. Disponível em: <http://revistas.pucsp.br/index.php/bakhtiniana/article/view/16717/14756>. Acesso em 20/10/2014. 
Quanto ao caráter informativo, verificamos que, na publicidade selecionada, assim como nos demais outdoors da campanha, não se divulgam produtos, apenas a marca. Por isso, à primeira vista, ele mais nos parece uma propaganda generosa de ideias, que faz um apelo à união de raças. Mas o nome da grife à direita nos lembra que o aspecto comercial está presente. Mais do que isso: as próprias relaçôes dialógicas propostas no texto são valorativas; logo, devemos procurar entendê-las melhor por meio do exame das formas da língua e das imagens.

A foto das crianças, uma loira e outra negra abraçadas e olhando fixamente para a câmera, está ligeiramente posicionada à esquerda da publicidade, para que se complemente o texto com o título da grife, à direita, United Colors of Benetton. As crianças não parecem estar vestidas e, além da diferença da cor, apresentam uma nítida diferença de expressão: o sorriso da loirinha está não apenas nos lábios, mas também nos olhos claros e bastante confiantes. Já a criança negra não sorri, ela está abraçada à branca, mas com os grandes olhos arregalados, fixos e meio assustados fitando a câmera, lábios bem fechados. O modo como ambas estão penteadas também é significativo: os caprichados (e angelicais) cachinhos loiros de uma e os dois pequenos tufos/coques pontudos e laterais da outra, muito caprichados também. As palavras constituem o logo da grife como nas demais: letras brancas sobre um retângulo verde, seguidas de um ponto final, o que a caracteriza como uma frase: em português, as Cores Unidas da Benetton. A frase, entấo, refere-se tanto à grife quanto às cores que se unem no abraço, graças à campanha UNHATE da empresa.

Quanto às palavras, ainda, é fácil notar que se apresentam como um patronímico, o lugar da convivência e união das raças, dialogando com o nome de países como USA: o mesmo número de palavras, a mesma ordem, o mesmo início, a mesma tonicidade. Segundo João de Almeida Santos, publicitário português, o sucesso, poder e liderança que se atribuem ao país, por analogia se transmitiriam àquele que se veste com a marca: "Trata-se [...] da mais pura ilusão ideológica: a alusão aos USA induz, subliminarmente, 
quem usa produtos Benetton a assumir-se como pessoa de sucesso, de poder, forte e afirmativa"19. De outra forma, a frase United Colors of Benetton dialoga também com o nome dado à campanha de que o anúncio faz parte pela repetição intencional do UN inicial - é preciso lembrar que existem o verbo inglês hate e o prefixo un, indicador de negação/oposição, mas não o neologismo Unhate.

Assim, está claramente explicitado no texto o discurso bivocal voltado para o objeto - tanto as crianças como os produtos comercializados pela marca, e voltado para outro discurso - o discurso não racista, de união dos povos. Esse discurso é reforçado pela imagem que, na realidade, é mais controversa do que acabamos de indicar, pois projeta uma união que vai além das raças: há nela uma polêmica velada entre o bom e o mau, o anjo e o demônio. Há, como diria Bakhtin, "uma alfinetada, uma indireta" a um outro discurso vigente, "o discurso hostil do outro" (2008, p. 224-225), apontando o modo preconceituoso como frequentemente é vista a relação entre raças. Isto é, os discursos não apenas dialogam com outros discursos para concordar, afirmar, refutar, ou mesmo antecipar as respostas e objeçóes potenciais, mas também para criar polêmica, como ocorre aqui, uma polêmica velada.

Como afirma Bakhtin, a "polêmica velada está orientada para um objeto habitual, nomeando-o, representando-o, enunciando-o" - neste caso, o preconceito racial, "e só indiretamente ataca o discurso do outro, entrando em conflito com ele como que no próprio objeto" - neste caso, na própria imagem há o conflito com o outro (2008, p. 224). Esse colorido polêmico do discurso manifesta-se na integração entre palavras e imagens que, enquanto propóem a união - cores unidas no abraço das crianças - também expressam e lembram a rejeição, na polêmica anjo x demônio. A ideia do outro, o discurso da discriminação e do preconceito, não entra pessoalmente no cartaz, apenas se reflete tensamente nele, determinandolhe de modo ativo a entonação apreciativa e os sentidos.

19 Disponível em: <http://joaodealmeidasantos.blogspot.com.br/2009/06/toscani-pos-publicidade-e-benetton.html> 
Algumas importantes questôes podem ser levantadas para finalizar esta análise e o texto. Em primeiro lugar, em relação ao gênero, observamos que, na relação dialógica polêmica proposta pelo texto, o caráter ideológico parece suplantar o caráter comercial, o que aproximaria o outdoor do gênero propaganda, distanciando-o da publicidade de modo geral ${ }^{20}$. Aliás, o próprio Toscani defende que o enorme espaço reservado à publicidade no mundo atual deveria ser mais bem aproveitado e utilizado socialmente, diferentemente do que comumente faz a publicidade, que apresenta um

paradisíaco mundo de imagens imbecis, irreal e mentiroso. Uma comunicação sem qualquer utilidade social. Sem força. Sem impacto. Sem sentido. Sem outra mensagem que seja a exaltaçáo grotesca de um modo de vida acintosamente yuppie, bastante agradável e bem-humorado (TOSCANI, 2003, p. 23 apud BORTOLUS, 2008, p. 67).

Mas é neste caráter intencionalmente controverso que a campanha investe a persuasáo, para que a grife seja lembrada de modo positivo. E justamente essa questáo nos faz recordar que estamos diante de uma publicidade, de caráter comercial, e não de uma simples e pretensa propaganda humanitária. Além disso, o tema permanece aberto à compreensáo responsivo-ativa do destinatário, importando, sobretudo, os questionamentos que se construirão em torno dele. Por outro lado, quando observamos o contexto em que a campanha se realiza, o confronto e a expulsão de povos indígenas na Argentina, as várias ações judiciais que a campanha suscita, nossa compreensáo do texto se aprofunda, e podemos inseri-lo mais facilmente como parte integrante desta sociedade capitalista, altamente competitiva e ávida por lucros, que conhecemos.

20 Embora possamos separar didaticamente os gêneros publicidade e propaganda, pelo caráter comercial ou ideológico que apresentam de modo predominante, reconhecemos que não é uma questão simples. 
E gostaria ainda de apontar outro aspecto da publicidade, aliás, a meu ver, de toda publicidade, que podemos observar aqui: sua proximidade com o gênero epidítico da antiga retórica. A finalidade do gênero epidítico era elogiar ou censurar homens e feitos, baseando-se nos valores bom/mau; belo/feio. Aqui na publicidade são a exaltação e o louvor da grife, da marca "generosa", que pretensamente não visa tão somente ao lucro, mas à modificação ética de comportamentos sociais. Nesse sentido, acrescento uma reflexão que me parece enriquecer bastante a compreensão do gênero publicidade/propaganda. Perelman e Olbrechts-Tyteca (1996), em seu famoso Tratado da argumentação, recordam funçōes fundamentais do discurso epidítico válidas para os dias atuais: são discursos que versam sobre valores - "o orador procura criar uma comunháo em torno de certos valores reconhecidos pelo auditório" (p. 56) - em nosso caso, trata-se do discurso humanitário da igualdade racial. Por isso mesmo, o discurso epidítico está muito próximo do discurso da educação, que se assenta sobre valores socialmente compartilhados (p. 53-60). É isso que fazem os autores da campanha da Benetton. Como um discurso do gênero epidítico, a campanha Unhate, por meio da exaltação e do louvor da própria empresa, visa a educar o destinatário, propondo uma comunhão em torno dos valores humanitários. A aposta é que as relaçôes dialógicas polêmicas, neste caso, levem à persuasão, por meio da associação entre valores, marca e consumo dos produtos.

Finalizando, a análise permite observar a produtividade dos conceitos da obra bakhtiniana ao expor alguns dos diálogos que este texto-publicidade enseja, levando-nos a uma melhor e mais profunda compreensão histórica e social dos discursos e posicionamentos axiológicos presentes. 


\section{REFERÊNCIAS}

BAKHTIN, Mikhail. Os gêneros do discurso. In: Estética da criaçáo verbal. 4. ed. São Paulo: Martins Fontes, 2006a. p. 261-306.

. O problema do texto na linguística, na filologia e em outras ciências humanas. In: Estética da criaçáo verbal. 4. ed. São Paulo: Martins Fontes, 2006b. p.307-335.

Reformulações do livro sobre Dostoiévski. In: Estética da criaçáo verbal. 4. ed. São Paulo: Martins Fontes, 2006c. p.337-357. Problemas da poética de Dostoiévski. 4. ed. Rio de Janeiro: Forense Universitária, 2008.

BAKHTIN, Mikhail; DUVAKIN, Viktor. Mikhail Bakhtin em diálogo - Conversas de 1973 com Viktor Duvakin. São Carlos: Pedro \& João Editores, 2008.

BAKHTIN, Mikhail; VOLOCHÍNOV, Valentin. N. Marxismo e filosofia da linguagem. Problemas fundamentais do método sociológico na ciência da linguagem. 2. ed. São Paulo: Hucitec, 1981.

BORTOLUS, Leila. Fragmentos de uma história: uma análise das campanhas publicitárias da Benetton. Mal-Estar e Sociedade. Ano I, n. 1. Barbacena, nov. p. 65-87, 2008. Disponível em <http://www.uemg.br/openjournal/index.php/malestar/article/viewFile/5/31>. Acesso em: 02. dez. 2012.

BRAIT, Beth. Análise e teoria do discurso. In: (Org.). Bakhtin: outros conceitos-chave. São Paulo: Contexto, 2008, p. 9-32.

BRAIT, Beth; CAMPOS, Maria Inês Batista. Da Rússia czarista à web. In: Bakhtin e o Círculo. Da Rússia czarista à web. In: BRAIT, Beth (Org.). Bakhtin e o Círculo. São Paulo: Contexto, 2009. p.15-30.

BRAIT, Beth; PISTORI, Maria Helena. C. A produtividade do conceito de gênero em Bakhtin e o Círculo. Alfa. Revista de Linguística, São Paulo, v. 56, n. 2, p. 371-401, 2012. Disponível em: <http://seer.fclar. unesp.br/alfa/article/view/5531/4343> Acesso em: 02. dez. 2012. 
BRANDIST, Craig. Rhetoric, Agitation and Propaganda: Reflections on the Discourse of Democracy (with Some Lessons from Early Soviet Russia). In: BAHUN, S.; RADUNOVIĆ, D. (Ed.) Language, Ideology, and the Human. ASHGATE PUBLISHING LTD, 2012, p.75-94.

CLARK, Katerina; HOLQUIST, Michael. Mikhail Bakhtin. Trad. J. Guinsburg. São Paulo: Perspectiva, 2008.

FARACO, Carlos Alberto. Círculo de Bakhtin. In: . Linguagem \& diálogo. As ideias linguísticas do Círculo de Bakhtin. São Paulo: Parábola, 2009. p. 11-44.

GRILLO, Sheila. V. C. Resenha. BOTCHARÓV, S. G.; GOGOMÍCHVILI, L.C. (Org.) Obras reunidas de M. M. Bakhtin. Bakhtiniana, Revista de Estudos do Discurso, São Paulo, v. 1, n. 1, p.170-174, 1 o sem. 2009.

MARCHEZAN, Renata Coelho. Sobre o pensamento bakhtiniano: uma recepção de recepções. Bakhtiniana, Revista de Estudos do Discurso, São Paulo, v. 8, n. 1, junho, p.82-94, 2013.

MEDVIÉDEV, Iúri Pávlovitch; MEDVIÉDEV, Dária Aleksándrovna. O Círculo de M. M. Bakhtin: sobre a fundamentação de um fenômeno. Bakhtiniana, Revista de Estudos Discurso, São Paulo, v. 9, n. esp, julho 2014.

MEDVIÉDEV, Pável. N. O método formal nos estudos literários. Introdução crítica a uma poética sociológica. São Paulo: Contexto, 2011.

GOMES, Neusa Demartini. Publicidade ou propaganda? É isso aí! Revista FAMECOS. Porto Alegre, n. 16, dezembro, p.111-121, 2001. Disponível em <http://www.revistas.univerciencia.org/index.php/famecos/article/view/272/206> Acesso em 11. set. 2012.

PERELMAN, Chaïm; OLBRECHTS-TYTECA, Lucie. Tratado da argumentaçáo. A nova retórica. Trad. Maria Ermantina Galvão G. Pereira. São Paulo: Martins Fontes, 1996. 
PISTORI, Maria Helena. Dialogia na persuasão publicitária. Bakhtiniana, São Paulo, Número 9 (1), p. 148-167, Jan./Jul. 2014. Disponível em <http://revistas.pucsp.br/index.php/bakhtiniana/article/ view/16717/14756> Acesso em: 02. dez. 2012.

SANTOS, João Almeida. Toscani, a pós-publicidade e a Benetton. Sextafeira, 26 de junho de 2009. Disponível em: <http://joaodealmeidasantos. blogspot.com.br/2009/06/toscani-pos-publicidade-e-benetton.html> Acesso em 15. fev. 2016.

SÉRIOT, Patrick. Préface. In: VOLOSHINOV, V. N. Marxisme et philosophie du langage. Les problèmes fondamentaux de la méthode sociologique dans la science du langage. Edition bilingue traduite du russe par P. Sériot et Inna Tylkowski-Ageeva. Limoges: Lambert-Lucas, 2010. p. 13-109.

SOUZA, Geraldo Tadeu. Boris Schnaiderman e Mikhail Bakhtin. In: BRAIT, B. (Org.). Bakhtin, dialogismo e polifonia. São Paulo: Contexto, 2009, p. 225-239.

VOLOCHÍNOV, Valentin.; BAKHTIN, Mikhail. A palavra na vida e na poesia. Introdução ao problema da poética sociológica (Anexo). In: BAKHTIN, M.; VOLOCHÍNOV, V. Palavra própria e palavra outra na sintaxe da enunciaçáo. (Org. aos cuidados de Valdemir Miotello). São Carlos: Pedro \& João Editores, 2011. p.145-181.

ZANDWAIS, Ana. Bakhtin/Voloshinov: condições de produção de Marxismo e filosofia da linguagem. In: BRAIT, Beth (Org.) Bakhtin e o Círculo. São Paulo: Contexto, 2009. p. 97-116. 